It is difficult to determine whether the author had any serious purpose behind his sketch. Very possibly he was using the incident primarily as an opportunity to string together a long line of puns, mostly on the idea of making hay out of leaves of grass. The references to the Bureau of Agriculture, to hemp, clover, hay, the name "Timothy," the occupations of cutting, mowing, and turning over, all seem to indicate that the author was mainly interested in constructing puns. The real intent of the sketch seems to have been for the amusement of the tables at Pfaff's or some other place where poets and writers would gather. Possibly because Mrs. Grundy appealed to such a limited audience, the magazine lasted only twelve weeks.

Illinois State University

WiLliam R. LiNNEMAN

\title{
WHITMAN AS THE NAZARENE: AN UNPUBLISHED DRAWING
}

Among the holdings in the William D. Bayley Collection at Ohio Wesleyan University is a letter from Edward Carpenter to an unidentified "Benjamin," ecstatically describing Carpenter's first meeting with Walt Whitman on May 2, 1877. In 1961 Gay Wilson Allen printed the text of the letter, ${ }^{1}$ but not the remarkable appendage to it which appears on the back cover of this issue: a sketch Carpenter made to illustrate his description of Whitman's face:

The thing which strikes one about his face is the great interval between his eyes and eyebrows. That 'space in which the soul seems to move' is very large. The eyebrows very much arched so as to make the bridge of the nose very long-the nose itself straight \& well-proportioned. The mouth and chin are covered with a fall of white hair, but the forehead is clear and high. As to his eyes of course it is impossible to put them into words-the impression they produce on me is of an immense, immense, background: Yet it is very characteristic of them that the pupils are small \& distinct, the likeness to Christ is quite marked. I suppose it comes in the high eyebrows. I send you a sketch (!) which will give you an idea of the proportions of the face. Put into it the extravagant prophetic look of genius, intense perceptive power, and as much sentiment as you like, and you have something like. ${ }^{2}$

We may probably assume that Carpenter's exclamation point signifies good humored acknowledgment of his poor drawing skill, and his stated intent is only to suggest the "proportions of the face"-especially, it seems, the relationship of eyes to eyebrows that he found so Christ-like. Nevertheless the sketch, depicting a rather narrow face, scanty beard, and thin, straight hair, is interesting precisely because it does not look at all like Whitman. Allen's note on the matter goes straight to the point: "The sketch looks much more like a conventional image of Christ than any of the photographs of Whitman except possibly the frontispiece of the 1855 edition of Leaves of Grass. It plainly shows Carpenter's idealization of the poet." ${ }^{3}$ Indeed that idealization continues as the enthralled Englishman goes on to tell of walking with Whitman in the streets of Philadelphia, later on the day of their meeting. Walt-leaning on the younger man's arm, "for one foot is still semiparalysed"-is portrayed as the adored cynosure of the common folk: "The 'bus drivers, the ferryboat men, jacks of all 
trades, stopped his way with greetings. One man jumped down off a dray cart. He had been a driver on Broadway, New York, 'hadn't seen 'Walt' for 3 or 4 years': tears stood in his the driver's eyes as he stood and held his hand and gazed hard in his face. . . . If he hears 'George' is ill, he must go 'right away' \& see him, if anyone is in trouble he lends a patient ear for any time: he is full of kindness, yet he unites this tenderness with the most wonderful strength and persistency \& selflessness. ..." Here is an image of Whitman like Ezra Pound's hearty, comradely Jesus, the "Goodly Fere," though softened by age (Whitman was fifty-eight) and slowed by a debilitating stroke.

When, almost thirty years later, in Days with Walt Whitman, Carpenter again recounted this heady first meeting with his idol, the facts, though elaborated and extended beyond those in the letter, remained virtually the same, and the idealization of the poet undimmed: "I was aware of a certain radiant power in him, a large benign effluence and inclusiveness, as of the sun. . . ."4 Interestingly enough, however, though the description of Whitman's face includes many of the same details, and again emphasizes the "high arch of the eyebrows," the reference to Christ-which earlier had been prompted largely by that feature-has disappeared, to be replaced by other, radically variant comparisons. First, the face is one of "majestic simple proportion, like a Greek temple as some one has said; the nose Greek in outline"; then, in a truly quantum leap from this Hellenic reference to an arrestingly primal one, the poet's head is reported to have impressed Carpenter "by its height, and by a certain untamed 'wild hawk' look, not uncommon among the Americans." $" 5$

Had this raptorial impression been dominant in Carpenter's mind at the time of the "Benjamin" letter, one wonders what kind of sketch he might have drawn. As it is, we have the Christ-like one, which, however cartoonish, serves as a graphic reminder of the urge among Whitman's "disciples"- as strong in John Addington Symonds, William Douglas O'Connor, Ellen Gilchrist and Richard Maurice Bucke as in Edward Carpenter-to idealize, if not indeed apotheosize, "The Good Gray Poet."

Ohio Wesleyan University

RANDALL WALDRON

\section{NOTES}

1 Walt Whitman as Man, Poet, and Legend (Carbondale: Southern Illinois University Press, 1961), pp. 155-158.

2 Allen, pp. 156-157.

3 p. 257.

4 (London: George Allen \& Unwin, Ltd., 1906), p. 6.

5 Carpenter, p. 7. 